received, to date, are Muir of Ord in the north, Glasgow in the south, Edinburgh in the east and Tobermory, Isle of Mull, in the west.

The fore-shock of December 24, 1946, associated with the main quake, was felt not only in Invernessshire and Argyll, but also as far south as Fenwick, Ayrshire.

The epicentre of this earthquake lies in the Inverness-Oban seismic zone, which includes the fracturesystem of the Great Glen fault. Interest attaches to the fact that the recent tremors indicate stressrelief in a part of this zone where only one other earthquake of the same order of intensity has been recorded hitherto ${ }^{1}$. This latter was noticed at Gairlochy, Spean Bridge and Roy Bridge, over a period of six seconds, between $22 \mathrm{hr}$. and $23 \mathrm{hr}$. (G.M.T.) on August 22, 1924, when it attained a maximum intensity of IV (C. Davison scale).

Regarding the most recent activities at foci in the same zone, adjacent to Spean Bridge, records indicate that tremors originated near Inverness in September ${ }^{2}$ and October $1901^{3}$ and near Oban in both December 1925 and May 1941. Thus, between 1901 and 1947 foci have been active in the sequence: Inverness, Spean Bridge, Oban, Oban, Spean Bridge, suggesting a return of stress-relief to the central region of the zone after previous manifestations of this relief in the north, centre and south of the zone, respectively.

Times and durations noted in the epicentral region lead to the conclusion that the quake of December 25,1946 , began about $17 \mathrm{hr}$. $2 \mathrm{~min}$. (G.M.T.) as a rumbling sound of low pitch which continued for about two seconds. This was followed by three sharp tremors, occurring over a period of about three seconds, the first of which exceeded the intensity of either of the others. The last tremor was followed by a further rumbling sound which became inaudible after about three seconds.

Close to the epicentre, effects of the three main tremors were compared to those of sudden explosions, such as the detonations of hand grenades. In a surrounding zone only one tremor was noticed, generally preceded, but not always followed, by a sound. Beyond this zone a weak tremor was felt, usually unaccompanied by any sound.

Some observers described sounds heard about the epicentre as being similar to the deep rumbling of a heavy vehicle passing over a bridge, or thunder, or gunfire at a distance. Others compared them to the roaring of wind, or to the noise of a train in a tunnel. At places remote from the epicentre, the sound was said to possess a harsh, rasping quality.

The intensity of this earthquake appears to have exceeded that of August 22, 1924, in the same locality (namely, IV (C. Davison scale)), for on this recent occasion not only were the chairs of several seated observers noticeably moved at Gairlochy and Spean Bridge, but also a plaster ceiling was thrown down in Achnacarry at the east end of Loch Arkaig; a chimney-pot dislodged from a house at the northeast end of Loch Laggan; two heavy shop-safes moved in Fort William, and windows, doors and crockery rattled at many places in the area. These, and similar phenomena, are consistent with a maximum intensity of about VI (C. Davison scale). Further, the position and form of the central disturbed area, and distribution of intensities within it, suggest a close association of this earthquake with the Great Glen fault-system. On the other hand, present information suggests there was no significant sympathetic movement in the Highland Boundary fault-system at or about the time when these recent Spean Bridge disturbances took place.

A weak fore-shock connected with this earthquake appears to have occurred at about $17 \mathrm{hr}$. $20 \mathrm{~min}$. (G.M.T.) on November 19, 1946, and a second one close to $24 \mathrm{hr}$. (G.M.T.) on December 23, 1946. The latter, which was noticed in Inverness-shire, Argyll and north Ayrshire, consisted of two tremors lasting about four seconds and three seconds respectively, separated by an interval of about two seconds.

The after-shock of January 5, 1947, would seem to have taken place at about $09 \mathrm{hr}$. $35 \mathrm{~min}$. (G.M.T.), when a slight rumble was heard in West Glen Roy and Glen Spean, having a duration of about three seconds.

'Nature, 114, 653 (1924).

Davison, C., Nature, 64, 527 and 601 (1901).

s Davison, C., "A History of British Earthquakes", 30, 43-56 (1924).

\section{INDUSTRY AND RESEARCH CONFERENCE AT BIRMINGHAM}

$\mathrm{T}$ HE first of the regional conferences on "Industry and Research" sponsored by the Federation of British Industries was held at Birmingham on March 25. The morning session, over which Sir Ernest Canning, vice-president of the Federation, presided, was devoted to "Research and Economic Recovery", and Sir Ernest, in opening the Conference, emphasized the vital importance of research, not merely in the evolution of new materials, processes and products, but also in the improvement of existing processes and products. He pointed out that it is a vital factor in promoting the more effective use of materials, labour and power, thus saving coal and other fuels; and while in the short term we must all work harder, the only long-term method of restoring our pre-war standard of living lies in the persistent application of the scientific method and scientific advances to our industrial technique and life. We cannot equip ourselves for the highly competitive struggle in the world's markets which in two or three years will follow the sellers' market if we postpone the prosecution of industrial research until the time when the application of its results is essential to strengthen our competitive power.

In his paper on "Industrial Research and the National Economy", Sir William Larke commented on the document "Economic Survey for 1947" that in industry alone resides the power of making good the shortages and the responsibility of obtaining maximum production from the resources of fuel, raw materials and man-power which the Government is largely responsible for making available for industry. He urged that the scientific method must be applied throughout, starting at the level of the boards of directors. Sir William referred particularly to the possibilities in the saving of fuel by technical investigation and control, the economies in the use of raw materials and the reduction of waste often achieved by technical research, and the contribution of technological investigation of processes and machine operation to the increase in output per man-year. These are short-term measures for immediate application, but the long-term measures, including fundamental research, are in some ways an even more important factor. Sir William believes that the technical colleges have a more important part to 
play than in the past, and he emphasized the need for a spirit of inquiry and the development of researchmindedness as a national characteristic.

In the second paper at this session, Dr. J. W. Jenkin dealt with Midland industries and their research needs. These industries are exceedingly varied and multifarious ; but there are some common factors, and whether the work be mechanical or scientific, real progress can only come from a ruthlessly objective study of all relevant facts and creative thinking to find relations between them and to devise the crucial experiments. There appears to be a need for a closer link between the scientific work characterizing the newer industries and the engineering inventiveness common in the older. This can often be supplied by making the same persons responsible both for the research results and their translation into practice. The bridging of the gap between the discovery and its commercial exploitation, the development stage, should not be left as a spare-time activity of those primarily responsible for administration, production or sales. Men are needed with wide sympathies to direct research away from over-emphasis on a restricted field of technology into closer liaison with development.

Sir Edward Appleton presided over the second session of the Conference, which dealt with industrial research in the Midlands. He commented on the increasing readiness of many scientific workers in universities and technical colleges to place their knowledge at the disposal of industry, but at the same time thought that the encouragement of cooperative action through the research associations is the most effective means of supplying the particular scientific knowledge which industry requires. $\mathrm{Mr}$. F. G. W. King, technical director of the Dunlop Rubber Co., Ltd., contributed a well-documented paper on Midland research organisations, activities and facilities, in which he suggested that since most of the industrial research in this large and varied region is carried out in the laboratories of the large firms, although related contacts spread all over the country, investigation of methods of increasing productivity, particularly the skilled study of flow production, and close co-operation between research units and their related groups in firms, research associations and universities ar $\epsilon$ required, in addition to further research. Such co-operation should be facilitated by fuller documentation of the broad fields of the research, to give a general idea of the problems studied, and he suggested that the research secretariat of the Federation of British Industries might help in the organisation of such documentation. Research, moreover, would only be fully effective if its results were known and appreciated by other experts and skilled workers in the industry. Appendixes to Mr. King's paper include an analysis of industries in the Birmingham region, and lists of industrial research in progress in technical colleges and universities, either in the region or outside the region, when specially related to its industries. The information relating to the universities was taken mainly from the "Notes on Current Scientiflc Researches in the United Kingdom" prepared for the Royal Society Empire Scientific Conference last year.

The concluding paper of the Conference, by Mr. J. C. Pearce, dealt with the smaller Midland firm and its application of research. Mr. Pearce suggested that the firm not large enough to provide one fulltime or part-time technical man to act in liaison with outside developments should treat its research association as a source of information and apply for information as and when required. It should give the staff of the Association opportunities of assessing the nature of its work and problems so that replies can be suited to its ability to give effect to them. The research associations should treat this information from individual firms as strictly confidential, but use it to build up that part of the current research programme dealing with experimental work directed towards the solution of specific problems common to the industry as a whole or to sections of it. $\mathrm{Mr}$. Pearce believes that the major functions of a research association, namely, the application of new knowledge through development and the dissemination of knowledge by intelligence activities, has been least satisfactorily solved.

In the discussion Mr. L. E. Lines, repudiating the suggestion that young industrial scientific workers should be excused military service, said that Great Britain is suffering from seeking too much security'. Dr. Quarrel pointed out that this year we shall have only one fifth of the number of scientific recruits which was available to industry in 1938, and only one half of the average number for the war years. Sir William Akers, in summing up, said that some of the observations indicated that in certain directions planning by the Government has been very incom. plete, and asked whether we should not now put all the technically and industrially fit people into the economic war.

\section{OIL PLANTS IN EAST AFRICA}

$\mathrm{T}$ HE plan for mechanized production of groundnuts in East Africa described in the recent White Paper (Cmd. 7030) and the inherent importance of all oleaginous crops to-day give added interest to an informative and well-documented review of oil plants in East Africa by A. Glendon Hill, director of the East African Agricultural Research Institute (E. Afr. Agric. $J ., 12,140$; 1947). It deals with ground-nuts, sesame and sunflower.

Ground-nuts. One of the most valuable of oil plants, with an oil content of nearly 50 per cent in the shelled nuts, it is widely grown by natives in East Africa, mainly for their own food; though it has not hitherto attracted the European farmer to any extent. In addition to oil, the nuts are rich in protein (about 30 per cerit), so that after extraction of the oil the press cake forms a valuable cattle food. Mr. Glendon Hill thinks this cake may in future be largely used for manufacture of artificial wool such as 'Ardil'. The main ground-nut areas of East Africa are the western, central, lake and southern provinces of Tanganyika, the eastern province of Uganda, and the Nyanza and coast provinces of Kenya. Only a small proportion of the crop is exported-21,000 tons in 1942. In 1936, 290,000 acres in Tanganyika and 167,000 acres in Uganda were under ground-nuts; and in 1944 it was estimated there were 400,000 native growers in Tanganyika.

Types and varieties, soils and manures, cultivation, harvesting, diseases and pests, and crop economics are described. There are a great number of varieties, which can be grouped into three main types, of which the 'bunch' or 'upright' is the most desirable, as exemplified by Virginia Bunch, which is early, drought-resistant, gives good yield and oil content, 